\title{
Financial malpractice as a destabilization factor of real financial reporting
}

\section{Финансијска малверзација као фактор дестабилизације реалног финансијског извештавања}

Pavle P. Parnicki

Assistant Professor, University Educons, Faculty of Business Economics, Sremska Kamenica, Republic of

Serbia, pavle.parnicki@educons.edu.rs

Danijela Živković Petrović

EPS - Electric Power Industry of Serbia, Lazarevac, Republic of Serbia, danojka81@gmail.com

Jelena Tucaković

Sremska Mitrovica, Republic of Serbia, jelenabranislav@mts.rs

Abstract: In the text of this scientific research we pointed out the natural correlation between the phenomenon of undertaking manipulative actions on financial and accounting reports by corporations, in circumstances of intensification, acceleration, as well as multiplication of fiscal pressure by the representatives of the management at the macroeconomic level. Also, with explications and scientific conclusions, we pointed out the destabilizing moments of consistent implementation of the principles of corporate governance, particularly in the circumstances of actual resorting to the use of different techniques of financial malversations by corporations or microeconomic entities as well as by individual households, because, in the etymological sense, they are also accepted as microeconomic subjects. At the same time, with the technique of optical laser guidance, we marked economic barriers and in the constellation of the subject matter without tendentious finger-pointing at individuals. Exclusively, using the technique of criticizing the contaminated state, the detection of neuralgic points of inhibition of optimal economic flows was performed, analysed through the prism of the need to respect the principles of corporate management.

Keywords: financial statements, manipulative accounting, evasion, entropy.

JEL classification: M41

Сажетак: Текстом научног истраживања из наслова указали смо на природну корелацију између феномена предузимања манипулативних радњи на финансијско - рачуноводственим извештајима од стране корпорација, у околностима интензивирања, акцелерације, као и мултипликације фискалног притиска од стране представника менаџмент естаблишмента, на макроекономском нивоу. Такође, експликацијама односно научним конклузијама указали смо и на дестабилизирајуће моменте консеквентног имплементирања принципа корпоративног управљања, управо, у околностима de facto, прибегавања употреби хетерогених техника финансијских малверзација од стране корпорација, односно микроекономских субјеката, као и од стране индивидуалних домаћинстава, јер се она, у етимолошком смислу, такође прихватају као микроекономски субјекти. Симултано, техником оптичко-ласерског навођења, означили смо економске баријере, а у констелацији предметне проблематике, без тенденциозног упирања прстом на појединце. Искључиво, техником критиковања контаминираног стања, извршена је детекција неуралгичних тачака инхибирања оптималних токова економије, анализирано кроз призму потребе респекта принципа корпоративног управљања.

Кључне речи: финансијско извештавање, манипулативно рачуноводство, евазија, ентропија JEЛ класификација: M41 


\section{Introduction}

Human consciousness, which is related to current analysis, and, simultaneously, specific per se, business consciousness, today, in the form of inherency, has unlimited value. The decision-making process in general, and in particular business-active provenance, is de facto determined by the quality of both human and corporate consciousness. Any, that is, every process, observed through the context of plausible and optimal functioning, i.e. continuity of implementation, with respect to the logic of the laws of nature, is long-lasting; therefore, in a strategic sense, exclusively in the circumstances of fulfilling the condition of mutual, i.e. multilateral satisfaction. Time, as a unity of position and moment, with simultaneous studious reflection on the advantages or disadvantages on one hand, as well as the chances vs. risks on the other hand, through the context of any or each individual case, is the only guarantee of the presumption of quality.

In particular, by scientific methods, first of all analysis vs. synthesis, then induction vs. deduction, as well as comparison of desktop derived data, with complementary explications, current research, we will confirm or refute the hypothesis about the existence of correlation in general, and then, also, direction and intensity of reaction of microeconomic subjects to economic policy measures, from the sphere of macroeconomic management. The determined scientific hypothesis implies, as we assume, another causalconsequential scientific hypothesis, that is, the fact that the initial reaction of microeconomic subjects will actually cause sophisticated feedback behaviour on the part of the creator of the business environment. The aim of this research is, in the circumstances of confirming hypotheses, at least in the form of striving for "panacea", which, is de facto true in practice, to expose the expediency ratio for mutual respect of needs and possibilities, regardless of economic factors, micro or macro. There is also, a consideration of a symptomatic provenance of whether affected legal entities, on the path of permanent market behaviour, can and/or must be exclusive, either in terms of severity and discrimination, or in terms of selectivity and preference. Also, in the context of more sophisticated thinking, whether the market, by vocation, must be of ruthless provenance, i.e. function according to the principle of extermination of competing corporations on one hand, or enable the implementation of recognized elements of monopolistic behaviour, on the other hand.

\section{Fraud indicators in financial reports}

False financial reporting, in its serious form, contributes to the devastation of the use value of financial and accounting reports, either through the aspect of direct use of information, which is incorporated in them, or as an information base for a complex analysis of corporate performance. If it is based on erroneous information, then a correctly performed analysis of financial and accounting reports will, in fact, not be valid. In the circumstances of non-existing accounting rules, a portal is opened towards a manipulative space of experimentation, in the form of heterogeneous abuses of financial reports (Savić, 2016, p. 109). In such circumstances, it is recommended to preventively review the quality (validity) of financial and accounting reports. In that sense, it is desirable to have a set of warning indicators, the movement of which can signal the presence of quasi-financial reporting. It is 
plausible, in the context of the suggestion, to pay more significant attention to fraud indicators. The management structures, especially internal auditors, must notice these signals, and investigate any circumstances that may indicate potential fraud. Thus, active fraud investigative practices by manufacturing companies will act as a deterrent to fraud in the future as staff will be aware that any financial fraud will be investigated and likely to be detected (Okoye \& Ndah, 2019, p. 113).

One of possible classifications of warning indicators of a fraud could be presented:

1. Factors that contribute to and allow fraud are: failure to record business transactions, which contributes to the absence of liability; absence of comparing existing assets with recorded amounts; conducting a business transaction without proper approval; non-application of prescribed controls, either due to the lack of, or due to the presence of incompetent staff; lack of computer expertise with supervisors; the ability to avoid controls using computer programs.

2. Signals that warn of the danger of fraud are: constant change in the number of employees; low employee morale; increasing the number of customer complaints; worsening of the revenue trend when the business, or organization as a whole, is doing well; the existence of an audit correction of a significant scope; write-offs of stock shortages without attempting to determine the cause; unrealistic anticipations regarding performance; rumours of conflict of interest; use of procurement contracts from, exclusively, one source (Irvin, 2014, p. 445).

3. Alarm signals at the organizational level are: unusual rapid growth of profits, especially in relation to the growth of competition; financial results, which are significantly better than those achieved by the competition, although there are no significant distinctions in business; unexplained changes in trends, or relationships in the financial reports; accounts or businesses located in "tax havens", without good business logic; decentralized operations with a weak system of internal reporting; revenue growth combined with lack of cash; over-optimistic, public announcements about future growth; too high debt ratio, or existence of difficulties in debt repayment, presence of business transactions at the end of the accounting period, which are complex, unusual or large-scale, non-application of the code of ethics of the organization; significant business transaction with related parties outside the normal course of business, potential short-term liquidation of firms, the existence of business arrangements which are difficult to understand and whose practical implementation in the corporation is visible.

Thus, the auditor's responsibility to obtain reasonable assurance that the financial statements do not contain intentionally generated irregularities and misstatements is a key to the independent audit of accounting fraud (Vlaović-Begović \& Tomašević, 2016, p. 99).

Exposure to risk, through the prism of manipulation in financial investments, implies the attitude from three broad aspects of activity, modern business entities such as:

- Corporate culture; 
- Method of assessing the elements of financial statements;

- The manner of exercising the right to choose in the process of financial reporting (Golden et al., 2006, p30).

The practice so far has shown that most manipulations in the financial statements are realized by manipulating expenses and income in the Income Statement and by manipulating liabilities and assets in the Balance Sheet. (Cvetković \& Petković, 2017, p. 317).

\section{Financial malpractice through the prism of income statement}

Income statement, as one of the essential financial and accounting reports, provides information on the success (profitability) of the company by presenting the realized income from corporate expenditures in a certain educational period. Its rationality is reflected in the fact that revenues versus expenditures are shown for a certain period of time, from which their difference is implied, in the form of profit versus loss, with significance to the observed period as well. The degree of reliability of financial and accounting information, incorporated in the income statement, starts to devalue due to financial malversations of balance sheets of profit and loss. Financial malversations of balance sheet items are systematized into two groups:

- $\quad$ false increase in income - frequent, with the intention of increasing profit, i.e., hiding losses;

- false reduction in income - frequent, with the intention that the income will not "bounce" too much above the previous, and especially the next accounting year, because too high "bouncing" in one year can create the impression of decline in the next year which may further reflect a decline in share prices, regardless of realized profits. For this reason, managers tend to show steady business growth rather than large revenue fluctuations

The most common strategies for false revenue increases are: double-entry of identical customer invoices; issuing fictitious invoices; ex ante revenue recognition; inflating revenues and substituting revenues from reserves. Revenue reduction can be carried out in addition to allowed and unallowed techniques which include: failure to issue invoices for permanent deliveries at the end of the accounting period; prolonging income in various ways; "black market sale"; not billing partially realized services; transfer of income to the next year, etc. Influence on the amount of net assets and profits by management of enterprises is more often performed through financial embezzlement on balance sheet income positions than on expenditure positions, as it is confirmed by the empirical studies. The tendency to show higher revenues in relation to the realized ones is detected in cases of management of the enterprises that record a constant profit propulsion, a low ratio of book value to market value as well and enterprises for which external analysts forecast revenue levels. Manipulative activities with balance sheet positions of income in the income 
statement, include: premature recognition of income from sales, increase in interest income, involvement of non-business (extraordinary) income; dealing with loans as with income from sales, swap transactions (substitution of tangible goods); non-confrontation of income and expenses (Jones, 2011, p. 46). According to the interpretations of the International Financial Reporting Standards, the income is confirmed in the circumstances of the delivered goods, i.e. invoicing, as well as in the circumstances of the concluded agreement, that, until the goods are taken over, they remain in the seller's warehouse. Likewise, "[comparison of] income vs. expense, which relates to an identical business transaction, or other business event, is recognized simultaneously, and this process is usually referred to as juxtaposition of income and expense" (International Financial Reporting Standards: IAS 18 - Revenues, 2003). We also systematize financial malversations of balance sheet positions of expenditures into two groups:

- false increase in expenses - with the intention of reducing profit, and consequently, income tax, as well as to burden the current period with expenses from the next period, in order to relieve the next period and increase the income in the current year, to increase the revenues from the following year by creating latent reserves.

- false reduction of expenses - with the intention of avoiding showing losses, hiding losses or increasing profits, in order to obtain managerial bonuses.

Most often, accounting procedures of false increase of expenses include: reporting bills for private expenses of the management staff as the expenses of the corporation; reporting fictitious expenditure amounts; aggressive liabilities write-offs and assets writeoffs; omission of cost allocation; receiving invoices for unperformed services from corporations which are responsible for recognizing higher revenues in their books; increase in depreciation costs and burdening provisioning costs beyond normal limits for nonexistent risks. Accounting procedures for false expenditure reductions frequently include: reduction of depreciation costs; removal of current expenses from the profit and loss account and their capitalization; transfer of current expenses to accruals; termination of posting of suppliers for expense accounts and deferral of expenses from the current business year. The results show that LDM is very effective in reducing risk if financial abuse is committed, although it may prove undeniable because more resources are needed to effect such a system that reduces the amount of help that will reach the target people (Musah et al., 2018, p. 148). The management of the corporations often manipulate the balance sheet positions of expenses in the income statement with the intention of recording the lowest possible current expenses, with a simultaneous, indirect representation of higher profit of the corporation. Furthermore, managers potentially manipulate expenses in order to avoid loss in business because any drop in profits and going to the loss zone, for the corporation, de facto, means a possible increase in interest rates on loans as well as a possible loss of current and future investors, which is a possible reduction in the number of employees. There are also examples of such corporations, which intentionally increase certain items of expenditure, in the manner of transferring future expenditures to the current accounting period. The basic motive for the explicit structure of behaviour is found in maintaining the current level of business results in order to avoid "sharp" evaluations in 
profit or in order to reduce the amount of profit at the end of the accounting year so to reduce or to completely evade the profit of the corporation. Malversations are a broader concept in which, as a subclass or subgroup, there are criminal acts in the financial statements that are only interesting for the theory and practice of auditing, due to the negative impact they may have on the financial statements (Petković, 2010, p. 9).

\section{Financial malpractice through the prism of balance sheet}

Forms of manipulative financial activities on balance sheet positions within the balance sheet, as a relevant financial accounting report, most often include: overestimation of receivables from debtors; manipulation of stocks of materials, goods and final products; overestimation and underestimation of obligations; absence of records of liabilities; etc. Analysing tangible and intangible assets, the management of the corporation achieves the impact on their value through improper implementation, i.e. abuse of the rules for activating expenditures, made in correlation with the subject's assets, as well as by overestimating and underestimating the residual value of assets, their lifespan, and the choice of write-off method. Activation or capitalization of expenses, which arise in correlation with tangible and intangible investments, is a procedure by which the incurred expenses are shown as an asset in the balance sheet. Capitalization of expenditures per se is not an instrument for fraudulent activities through financial - accounting reports. Activation of subsequent expenditures in fixed assets, interest costs (financial expenses), investments in development costs as prominent examples of expenditures - the subject of capitalization becomes an instrument of fraud, if the conditions for capitalization prescribed by the standards haven't been fulfilled. Explicit options of influencing the business (financial) result against the capital of the corporation by overestimating assets and underestimating liabilities are potentially the cause of a lower or higher level of devastation, particularly, the expressive power of the balance sheet. Simplified (non-)behaviour, in fact, generates latent losses, and balance sheets, burdened with latent losses, trace the activities of the corporation's management structures towards making bad business decisions. Most often, the objectification of high, latent losses is a signal of the impending entropy (disintegration of the business system) of the corporation.

In particular, when evaluating fixed assets, management structures and accountants use the "assessment" method (Malinić, 2009, p. 53), with the intention of achieving a perceived picture of financial position and corporate success. The constituent of the corporation's business performance indicator of inherent importance is inventory. Success compared to overall business of the corporation are determined by proper, i.e. efficient inventory management. Validation of inventories of materials can be used to perform fraudulent activities in the balance sheet and in many corporations inventories constitute a significant part of assets. Values are manipulated more often than stocks because they are relatively easy to detect. Corporations for which a sound financial position is characteristic, respecting all relevant ratio indicators which lead to such a conclusion, are de facto able to service obligations according to creditors respecting the currency date clause, while difficulties in settling obligations indicate problems in the business of the same. Certain liabilities, by their nature, indicate valuations particularly on balance sheet positions in the 
balance sheet which implies an increase in the value of assets. However, liabilities which arise in addition to the simultaneous occurrence of expenses, will imply tangential evaluations both in the structure of the balance sheet and in the structure of the income statement. Susceptibility to manipulative actions is higher in correlation with liabilities if fraudulent activities can extend to both representative balance aggregates.

Fraudulent actions with property (real estate, machines, devices, equipment, land, long-term plantations, basic herd, etc.) are mainly based on overestimation or underestimation of its value. Financial malversations with assets are mainly due to ex ante reduction of certain costs (depreciation) or presenting it in the balance sheet as valuable as possible, with the intention of misleading future investors. Understanding the process of intangible assets is the basis of the managerial decision process (Petković et al., 2020, p.10).

\section{Financial malpractice through the prism of cash flow reports}

Cash flow reporting enables the analysis of a corporation's performance from the aspect of a diametrically different perspective in relation to the balance sheet and income statement. Cash flow reporting is in the function of assessing the corporation's exposure to financial risks, and more in-depth analysis makes it possible to place it in the function of detecting early warning signals about the corporation's financial position. It is definitely possible to reveal the effects of certain accounting policies with the help of subject, financial accounting report and consequently to reveal the quality of accounting profit from the income statement. Financial reporting according to the cash basis of accounting, in addition to the cash itself, includes cash equivalents that primarily serve to settle short-term cash liabilities (Andrić \& Vuković, 2018, p.53). The explicit circumstances make the statement of cash flows particularly plausible for detecting the eventual presence of creative (manipulative) accounting practice, which is always accompanied significantly by high risk.

There are two grounded methods for manipulating operational activities in cash flow reports:

1. Maximizing cash incomes based on business activities - when the corporation involves incomes from the sale of assets in cash incomes based on business activities in addition to incomes from business transactions. By showing as many incomes as possible, as well as incomes from business activities, the corporation wants to show the best possible business results;

2. Minimizing cash outflows based on business activities are circumstances in which corporations tend not to show as many outflows as possible based on business activities or to transfer them to outflows based on investment or financial activities, by which they expand everything that is considered to be the outflow, from investment and financial activities, tending to present the corporation as successfully as possible in this way. 
Empirical research points out four essential methods of financial fraud on the balance sheet items of a corporation's cash flow statement:

- Transfer of cash inflows based on financial activities to inflows based on business activities;

- Transfer of cash outflows based on business activities to outflows based on investment activities;

- Inflating cash flows based on business activities using acquisitions either by realizing a segment or the entire corporation;

- Increasing cash flows from business activities using additional or "auxiliary" activities (Schilit \& Perler, 2010, p. 190).

The set of magic tricks, under the unified name "Robin Hood", is the most appropriate actual concept of financial manipulation through the prism of cash flow reports, and by the management structure of the corporation. In general, "poor" parts are constituted by cash flows from business activities, which investors analyse more deeply, and "richer" parts are filled with cash flows from investment and financial business activities. The share of institutional investors on the stock exchanges of developed countries is about $60 \%$. (Doğan, 2020 , p. 41). By the arrangement of potential, explicit form of financial malversation activities, the general premise manipulates the conclusion, where corporations, i.e. their management structures, have at their disposal a "wide range" of possibilities or transfers of certain cash inflows into operating activities or transfers, certain cash outflows from business to other activities.

\section{Financial malpractice through the prism of taxes}

Frequently, the reason for financial manipulation through the aspect of taxes, as well as fraudulent activities in financial reports, is manifested through tendentious payment of reduced income taxes, achievable either by reducing revenues or increasing costs which lead to reduced realized profits. Tax evasion is most often a means of achieving personal goals and at the same time higher personal earnings of the perpetrator of fraud. In the USA and in the countries of the European Union, the tax authorities hire additional auditors with the goal of better control of tax returns and prevention of tax evasion and these are most often forensic accountants.

Non-payment or tax avoidance (a phenomenon called evasion) is analysed through the prism of two aspects: legal, i.e. vs. plausible tax evasion; illegal i.e. punishable tax evasion. The full use of all possible forms of tax reduction approved by the law is particularly the mantra of legal tax evasion. Evasion, on the other hand, represents nonpayment of legally determined tax obligations. Tax evasion differentiates the following types:

Double bookkeeping - one book is shown to the tax authorities, and the actual turnover is recorded in the others; 
- Unreported work, which is paid in cash and the amounts of which are not included in the tax return; it is not a sin to work part-time and earn additional income but that income must be reported to the state;

- Giving compensation in kind or in return as the original form of exchange between people (barter). Such transactions should be reported to the tax authorities; however, they are subject to tax;

- In some countries, even tips have to be reported to the tax authorities and taxes have to be paid for them; however, it is very difficult for the tax authorities to track down this type of income because only the recipient knows how much money he has received;

- Payment for goods or services in cash and not through payment transactions, because it is difficult for the tax authorities to disclose all payments for goods or services which were made in cash and not through payment transactions.

In fact, the 'Maginot line' is thin between tax avoidance and tax evasion. In a given context, namely, any tax evasion can relatively easily transfer (i.e., slip) into a zone of tax evasion. Most often, economic entities manipulate: corporate income tax, then, individual income tax, value added tax, employee salary tax and property tax. We have concluded that most of the fraudulent actions, through financial and accounting reports either directly or indirectly, point to the phenomenon of evasion, that is, undertaking activities regarding the illegal avoidance of servicing tax levies. Fraud in income or expenditure led to a decrease or increase in profits and thus to a decrease or increase in taxes. The presentation of lower levels of income or higher levels of expenditure in the financial and accounting reports of corporations tends towards reduced profit, i.e., less paid money as income tax. The amount of money paid as tax on a corporation's property is determined by techniques of direct influence, that is, through the prism of heterogeneous forms of manipulating the value of the property in the balance sheet. With the intention of paying lower levels of property taxes, corporations generally tend to implement lower asset values.

Frequently, fraudulent activities through the prism of all forms of taxes are represented in the following way:

- conscious non-recording or omission of a critical group of revenue items;

- excessive implementation of tax incentives;

- double tax bookkeeping;

- realization of falsified entries in business books, both on the side of expenses and on the side of income, as well as on the side of assets and liabilities

- reporting personal expenses of an individual as corporate expenses - socialization of expense, as a phenomenon of negative provenance;

- implementation of illegal tax breaks; 
- various forms of money laundering (Albrecht et al., 2009, p.571).

Financial and accounting reporting of corporations (companies, banks, insurance companies, institutions, etc.) is aimed at both internal and external stakeholders. Internal financial statements are primarily used by the corporation's management and it is the one which directly determines the degree of their reality and can influence it. Therefore, it is logical that internal financial reporting should be realistic in order to have a realistic basis for making business decisions. Individuals or management may be involved in committing an act of fraud. In the case of natural persons, accounting fraud would generally involve theft of property (Chimonaki, 2021, p. 59). External financial statements are used, among other things, to calculate the corporation's tax liabilities as well as to make business decisions by potential investors vs. creditors. There is a "natural" need for the corporation's management to harmonize external financial reports with the corporation's needs (to pay less taxes, to attract new investors, etc.). Researchers suggest that trained professionals such as professional forensic accountants should conduct an investigation, where there is sufficient evidence to do so. The provisions of the rules and government restructuring of corruption agencies should be applied for better performance (Ehioghiren, \& Atu, 2016, p. 267).

\section{Conclusion}

Members of the management structures, at the macroeconomic level, are undoubtedly elected for the basic reason and that is the management of all resources of any country or each country by creating a business environment, i.e., generating optimized (in mathematics known as asymptotic approach to the target point) measures of economic policy which will, continuously, influence microeconomic entities in an atmosphere of positive provenance. Although, at first glance it seems complex, the definition is nevertheless extremely simplified. Different representatives or economic policy or macro level makers of, with all due respect, either temporary or strategic time dimensions, should in fact contribute to creating a positive business climate, metaphorically expressed as "runways" from where microeconomic entities, that is, corporations take off and land. Corporations, by vocation, certainly pay various forms of fiscal obligations, particularly with the intention of optimal functioning of macroeconomic entities, which will, according to the feedback function system, by creating an optimally favourable business climate, in fact, achieve motivational influence on microeconomic entities. Based primarily on explicit desktop scientific research, we can indisputably confirm a significantly high degree of correlation, then direction, as well as a highly sophisticated but also propulsive level of response of microeconomic entities (corporations), namely to the generated and implemented economic policy measures from the domain of macroeconomic management. A rhetorical question arises, taking into account the explicit arrangement in the relation: fiscal servicing optimization of the macroeconomic environment - significantly motivated corporations, whether today, after decades of devastation of a given law of functioning of a causaleffective chain, macromanagement acts simultaneously i.e. automatically, having lost touch with the purpose of their existence and thus criticism of the academic environment is necessary, precisely with the intention of returning to the roots of the reasons for its 
inauguration. Considering the fake dynamic and turbulence of relations, regarding a given relationship, rhetoric also requires finding a rational answer for whether, based on the above scientific research when there are extremely unreasonable fiscal levies, cut by government officials, it will be justified avoidance or illegal non-payment of the taxes to the treasury. There is even the current situation with a declared pandemic of the virus, which marginally, on the already existing factors, created a whole spectrum of new inhibiting ones on the energy flow of economic activities, that is, on the side of microeconomic entities vs. corporations, and, above all, with private ownership. Instead of a more flexible vs. differently set concept of business philosophy, on the side of macromanagers and with the aim of bringing to the surface otherwise stumbled economies, fiscal pressure on lower and lower economic entities and even on households is increasing.

A spiral of mistrust is created. By avoiding economic policy, in the competence of which the relaxation of microeconomic subjects would be more significant, and analysed through the prism of fiscal levies, at some point respecting the laws in nature, a turning point will occur, called entropy, as a complete economic collapse. With current explications, that is, research, simultaneously criticizing the phenomenon of contaminated economy, we want to point out the urgent need for revitalization, not exclusively economic, but holistic consciousness. With the presented considerations, we did not justify any economic or business entity, macro or micro or individual households, their reactions to certain moves of others, but there was a natural human need to point out more than present general problem, that is, pointing to potential getting out of the economic mire.

\section{References}

Andrić, M. \& Vuković, B. (2016). Revizija javnog sektora. Univerzitet u Novom Sadu, Ekonomski fakultet u Subotici.

Albrecht, S., Albrecht, C. \& Zimbelman M., (2009) Fraud Examination and Prevention, Ohio, Thomson - Soult - Western.

Chimonaki, C. (2021), Theoretical analysis of creative accounting: fraud in financial statements; Machine Learning Applications for Accounting Detection and Fraud Detection., IGI Global.

Cvetković, D., \& Petković, A. (2017), Kreativno računovodstvo: od upotrebe do zloupotrebe. Ekonomski vidici, 4, 307-322.

Doğan, M., (2020), Institutional ownership and enterprise value: a study of the BIST production index. Ekonomika, 66(4), 29-46. Doi: https://doi.org/10.5937/ekonomika2004029D

Ehioghiren, E. E., \& Atu, O. O. K. (2016). Forensic accounting and fraud management: Evidence from Nigeria. Igbinedion University Journal of Accounting, 2(8), 245-308.

Golden, T., Skalak, S. \& Clayton, M. (2006). A Guide to Forensic Accounting Investigation, USA, John Wiley \& Sons. 
Irvin, N. G. (2014). CIA Review, Gleim Publications, Part II, Conducting the Internal Audit Engagement, $11^{\text {th }}$ edition.

Jones, M. (2011). Creative Accounting, Fraud and International Accounting Scandals, UK, John Wiley \& Sons.

Musah, A., Ocansei, F. \& Akomeah, E. (2018). Financial abuse and the risk of financial abuse by NGOs in Ghana: a donor's perspective. Academic Journal of Economic Studies, 4(3), 146-153.

Malinić, D. (2009). Cash-flow kao instrument otkrivanja poslovno-finansijskog rizika, SRRS. Zbornik radova XL Simpozijum. „40 godina Računovodstva i Poslovnih finansija dometi i perspective", Beograd: Savez računovođa i revizora Srbije.

Okoye, E., \& Ndah, E. N. (2019). Forensic accounting and fraud prevention in manufacturing companies in Nigeria. International Journal of Innovative Finance and Economics Research, 7(1), 107-116.

Petković. A. (2010). Kriminalne radnje u finansijskim izveštajima. Forenzička revizija. Novi Sad.

Petković, M., Krstić, B. \& Rađenović, T. (2020). Accounting -based valuation methods of intangible assets: Theorethical overview. Ekonomika, 66(1), 1-12. Doi: https://doi.org/10.5937/ekonomika2001001P

Savez računovođa i revizora Srbije (2003). Međunarodni standardi finansijskog izveštavanja - MRS 18 - Prihodi, Beograd, paragraf 19.

Savić, B. (2016). Uloga i značaj računovodstvene fleksibilnosti za upravljanje odnosima s investitorima. Anali Ekonomskog fakulteta u Subotici, 35, 109-128.

Schilit, M. H. and Perler, J., (2010) Financial shenanigans - How to detect accounting gimmicks \& fraund in financial reports (third edition), New York, McGraw-Hill.

Vlaović-Begović, S., \& Tomašević, S. (2016). Odgovornost revizora za otkrivawe računovodstvenih prevara. Škola biznisa, 1, 89-101. 